PENERAPAN STRATEGI PEMBELAJARAN AKTIF TANGGAPAN

AKTIF UNTUK MENINGKATKAN HASIL BELAJAR PADA MATERI

POKOK UNDERSTANDING EXPRESSION MATA PELAJARAN

BAHASA INGGRIS SISWA KELAS VIII-F SEMESTER GANJIL DI SMP NEGERI 1 SITUBONDO TAHUN PELAJARAN 2018/2019

\author{
${ }^{1}$ Anisah Nurhidayati \\ ${ }^{1}$ SMP Negeri 1 Situbondo
}

Received: July 25, 2021 Revised: July 30, $2021 \quad$ Accepted: Augst 5, 2021

\begin{abstract}
ABSTRAK
Bahasa Inggris merupakan salah satu mata pelajaran umum yang sudah dikurikulumkan pada tingkatan SD, SMP, SMA sebagai mata pelajaran bertaraf Internasional. Dalam pelakasanaanya siswa diajarkan untuk memahami arti kata, membaca, dan mendengar. Akan tetapi pada proses pembelajaran siswa masih mengalamikesulitan dalam menguasai Bahasa Inggris dikarenakan keanekaragaman dalam tenses, grammar, vocabulary dan jenis kata. Namun, kesulitan dalam pembelajaran kosa kata kalimat dan pengucapannya Dengan adanya Strategi Pembelajaran aktif Tanggapan Aktif diharapkan dapat meningkatkan aktivitas dan hasil belajar. Desain penelitian menggunakan PTK. Teknik pengumpulan data berupa observasi, wawancara, tes dan dokumentasi. Berdasarkan hasil analisa data yang telah dikemukakan di bab IV dapat diuraikan sebagai berikut: 1) Penerapan Strategi Pembelajaran aktif Tanggapan Aktif materi pokok Understanding Expression Mata pelajaran Bahasa Inggris sangat efektif. 2). Penerapan Strategi Pembelajaran aktif Tanggapan Aktif dapat Meningkatkan Hasil Belajar mencapai $18 \%$ dari $76 \%$ siklus I meningkat menjadi $94 \%$ siklus II materi Understanding Expression Mata pelajaran Bahasa Inggris.
\end{abstract}

Kata Kunci : pembelajaran aktif tanggapan aktif, Hasil Belajar, Bahasa Inggris

Kemampuan siswa dalam berbahasa Inggris pun masih perlu ditingkatkan, dengan cara memberikan target kepada siswa untuk mampu menguasai empat komponen yaitu, listening, speaking, reading, dan writing. Di antara kempat kemampuan di atas, berbicara merupakan persoalan tersendiri yang harus dikuasai oleh siswa, yang menjadi perpaduan kemampuan antara otak, olah kata atau kalimat dan kemampuan mendengarkan. Persoalan yang sering ditemuisiswa memiliki kemampuan dalam bahasa Inggris tetapi tidak bisa mengucapkan dengan benar. Dengan kata lain, kemampuan siswa bertata bahasa masih pada tahapankompetensi (competence) belum sampai pada tahap performansi 
(performance). Halini dapat dilihat dari nilai mereka yang masih di bawah KKM dari hasil pre test. KKM bahasa Inggris di SMP Negeri 1 Situbondo adalah 70, baik pada pencapaian pengetahuan maupun keterampilan. Kendala yang paling sering muncul adalah rendahnya kemampuan mereka dalam hal keterampilan berbicara. Pendapat serupa juga diungkapkan oleh L Woodrow dalam jurnal RELC tahun 2006, tentang"second language anxiety has a debilitating effect on the oral performance of speakers of English as a second language".

Penyebab rendahnya nilai siswa dipengaruhi empat faktor. Pertama, adanya sekolah dasar yang belum mendapatkan pelajaran Bahasa Inggris, sehingga sulit bagi siswa untuk mampu berbicara bahasa Inggris dengan baik. Kedua, kurangnyapraktik yang dilakukanbaik di sekolah ataupun di rumah yang menyebabkan pengucapan yang kurang tepat. Ketiga, penggunaan metode yang kurang tepatdalam proses pembelajaran Bahasa Inggris. Penelitian ini akan dilakukan di SMP Negeri 1 Situbondo kelas VIII-F. Hal ini dikarenakan dari hasil wawancara dengan siswa pada saat observasi awal diketahui bahwa ketuntasan belajar sebesar 50\% dari 17 siswa di SMP Negeri 1 Situbondo menganggap bahwa mata pelajaran Bahasa Inggris merupakan mata pelajaran yang membosankan karena cara mengajar guru selama ini hanya dengan ceramah dan penugasan sehingga terlihat monoton. Ketuntasan belajar secara klasikal hanya mencapai 50\%. Banyak para siswa yang kesulitan memahami dan mencerna mata diklat bekerjasama dalam satu tim, apalagi mengaplikasikan dalam kehidupan sehari-hari, hal ini diantaranya disebabkan tidak terbiasa berpikir kritis, analitis dan argumentatif serta kurang terbiasa dalam bertanya jawab selama proses pembelajaran berlangsung.

Keempat, adanya anggapan bahwa berbicara dalam bahasa Inggris merupakan sesuatu yang „baru ${ }^{e e}$ karena tidak ditemui dalam lingkungannya. Diantara beberapa faktor tersebut, penggunaan metode yang kurang tepat menjadi poin utama, oleh karena ituupaya yang perlu dilakukan untuk meningkatkan proses pembelajaran Bahasa Inggris adalah dengan menggunakan strategi pembelajaran tanggapan aktif.

Salah satunya strategi pembelajaran aktif tanggapan aktif yaitu siswa diminta untuk memberikan pendapat berdasarkan masalah yang diajukan oleh guru sesuai dengan materi yang akan dibahas. Dari beberapa contoh model 
pembelajaran aktif tersebut peneliti tertarik untuk strategi pembelajaran aktif tanggapan aktif yaitu siswa diminta untuk perdebatan serius sehingga siswa mampu menyelesaikan suatu masalah dengan mandiri. Harapan strategi pembelajaran aktif tanggapan aktif yaitu siswa mampu membuat pertanyaan dan menjawabnya dari siswa lain atau kelompok lain. Tujuan utamanya adalah siswa mampu mengetahui informasi yang diberikan oleh temannya.

Hasil belajar dipengaruhi oleh kemampuan, keaktifan dan kualitas antar komponen pendidikan. Sebagai sarana penunjang, suatu metode pembelajaran adalah strategi yang digunakan dalam belajar mengajar.

Semakin baik pengajar menguasai dan menggunakan strateginya, maka makin efektif pula pencapaian tujuan belajar.

\section{Guru B.Inggris}

Penerapan strategi pembelajaran tanggap aktif:

1. Kembangkan suatu pertanyaan yang berkaitan dengan sebuah isu kontroversial yang berkaitan dengan materi pelajaran yang akan dibahas.

2. Buatlah dua atau empat sub kelompok di dalam masing-masing tim untu memberikan tanggapan aktif.

3. Mulailah memberikan tanggapan aktif dengan menyuruh para juru bicara itu menyampaikan pandangan-pandangan mereka. Mengaculah pada proses ini sebagai "argumen-argumen pembuka".

4. Masing-masing sub kelompok memilih juru bicara, sebagai wakil kelompok.

5. ketika siswa berpikir bahwa sudah cukup, akhiri tanggapan aktif dengan menarik kesimpulan

Gambar 2.1 Diagram Kerangka Konseptual 
Peneliti melaksanakan dua siklus untuk menerapkan Strategi Pembelajaran aktif tanggapan aktif dalam upaya meningkatkan hasil dn belajar siswa. Siklus dalam pelaksanaan ini terdiri dari empat tahapan yaitu rencana, tindakan, observasi dan refleksi. Keterbatasan waktu yang diberikan oleh sekolah maupun keterbatasan yang dimiliki oleh peneliti diantaranya: biaya, waktu, dan tenaga maka ditetapkan 2 siklus dalam penelitian di SMP Negeri 1 Situbondo. Hal-hal mengenai rencana pelaksanaan siklus tersebut diuraikan sebagai berikut:

\section{Perencanaan}

Tahap ini merupakan tahap merencanakan segala sesuatu yang akan dilakukan dalam penelitian. Kegiatan yang dilakukan dalam tahap perencanaan ini adalah sebagai berikut:

1. Menetapkan dan memilih pokok bahasan dengan pelaksanaan dua siklus.

2. Menyusun program silabus dan rencana pembelajaran untuk masing-masing pokok bahasan yang mengacu pada Penerapan Strategi Pembelajaran aktif tanggapan aktif.

3. Mempersiapkan artikel yang berhubungan pasar

4. Waktu yang digunakan proses belajar mengajar pada tiap-tiap pertemuan yaitu 2x40 menit dengan rincian sebagai berikut:

a. 10 menit digunakan untuk kegiatan pendahuluan;

b. 60 menit digunakan untuk kegiatan inti;

c. 10 menit digunakan untuk kegiatan refleksi dan penutup.

5. Mempersiapkan pertanyaan-pertanyaan yang digunakan untuk wawancara dengan guru dan siswa mengenai tanggapan terhadap penerapan strategi pembelajaran aktif tanggapan aktif yang telah diterapkan peneliti dalam proses belajar mengajar.

6. Membuat soal-soal pertanyaan untuk ulangan harian.

7. Membuat lembar observasi yang digunakan peneliti untuk mengamati hasil belajar siswa.

\section{Tindakan}

Hal-hal yang dilakukan peneliti pada pelaksanaan tindakan ini adalah peneliti berperan sebagai guru dan peneliti melakukan tindakan berdasarkan pada perencanaan yang telah dibuat. Tindakan yang dilakukan difokuskan pada upaya 
meningkatkan hasil belajar siswa dari rendah menjadi tinggi penerapan strategi pembelajaran aktif tanggapan aktif. Pada siklus I ini peneliti melaksanakan tindakan. Adapun langkah-langkah penerapannya secara garis besar sebagai berikut:

\section{Siklus I:}

a. Kegiatan pendahuluan

Guru memberikan apersepsi kepada siswa sesuai dengan materi yang akan dibahas

b. Kegiatan Inti

Pada kegiatan ini peneliti menerapkan strategi pembelajaran aktif tanggapan aktif dengan langkah-langkah sebagai berikut:

\section{Kegiatan Penutup}

Tahap refleksi ini merupakan tahap yang dilakukan peneliti untuk menilai hasil kegiatan belajar siswa dari tindakan yang telah dilaksanakan. Peneliti melakukan refleksi dengan cara mengevaluasi hasil belajar siswa dengan Strategi Pembelajaran aktif Tanggapan Aktif yang telah dilaksanakan.

dan II dengan hasil penelitian yang diperoleh sebagai berikut:

Hasil belajar siswa dalam kompetensi dasar menerapkan fungsi sosial, struktur teks, dan unsur kebahasaan teks interaksi interpersonal lisan dan tulis yang melibatkan tindakan meminta perhatian, mengecek pemahaman, menghargai kinerja, meminta dan mengungkapkan pendapat, serta menanggapinya, sesuai dengan konteks penggunaannya dilihat tabel berikut :

Tabel 4.1

\section{Hasil Belajar siswa Prasiklus}

\begin{tabular}{|c|c|c|}
\hline Nilai Siswa & Jumlah siswa & Persentase \\
\hline$\geq 70$ & 17 siswa & $50 \%$ \\
\hline$<70$ & 17 siswa & $50 \%$ \\
\hline
\end{tabular}

Gambar 4.1 Persentase Prasiklus

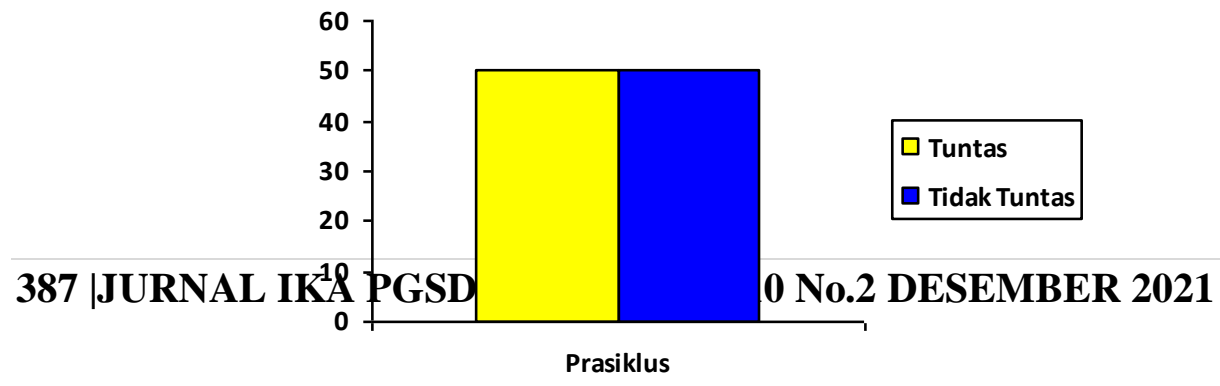




\section{Pelaksanaan Siklus 1}

Pertemuan Pertama

Adapun langkah-langkah yang diambil oleh guru dengan dibantu oleh peneliti dalam menerapkan strategi pembelajaran tanggapan aktif pada pertemuan pertama adalah sebagai berikut: Kegiatan pendahuluan dilakukan selama 10 menit dengan guru memberikan apersepsi kepada siswa sesuai dengan materi yang akan dibahas. Guru menanyakan tentang pengertian Understanding Expression. Kegiatan inti dilakukan 60 menit dengan guru mengembangkan sebuah pernyataan yang kontroversial yang berkaitan dengan materi Understanding Expression. Contohnya tahukah kamu tentang Understanding Expression? Apakah Understanding Expression. Siswa ada yang menjawab ya dan ada yang menjawab tidak. Guru membuat dua sampai empat sub kelompok dalam masingmasing kelompok untuk memberikan tanggapan.

Tiap kelompok mendiskusikan tentang macam Understanding Expression. Siswa mempresentasikan dengan mewakilkan tiap kelompok untuk membacakan hasil diskusi kelompok. Guru meminta siswa untuk melanjutkan kembali tanggapan. Pada saat yang tepat akhiri tanggapan. Kegiatan penutup dilakukan selama 10 menit dengan guru memberikan tugas pelajaran rumah untuk menyeimbangkan pengetahuan. Siswa yang telah didapat melalui diskusi

Pelaksanaan pertemuan pertama siswa yang ditunjuk menentukan anggota kelompok. Siswa masih merasa agak kaku dengan lingkungan kelompok yang kurang kondusif. Namun pada kesempatan siswa untuk berfikir kreatif pada saat mengerjakan soal-soal yang diberikan guru. Siswa saling menukar jawaban untuk dikoreksi dengan bimbingan guru, hal ini dilakukan untuk meningkatkan hasil belajar.

\section{Pertemuan Kedua}

Pelaksanaan pertemuan kedua ini mengacu pada kompetensi dasar yaitu mengidentifikasi Understanding Expression. Guru mempersiapkan dua sampai empat kursi untuk juru bicara pada kelompok. Setelah mendengarkan argument pembuka, hentikan debat dan kembali ke sub kelompok. Setiap sub kelompok memilih juru bicara, usahakan yang baru. Guru meminta siswa untuk melanjutkan kembali tanggapan. Pada saat yang tepat akhiri tanggapan. Kegiatan penutup 
selama 10 menit guru memberikan tugas pelajaran rumah untuk menyeimbangkan pengetahuan. Siswa yang telah didapat melalui diskusi.

Saat proses belajar mengajar berlangsung, peneliti dibantu oleh dua orang teman sebagai observatory untuk mengetahui tingkat hasil belajar siswa yang dicapai. Peneliti juga mengadakan kolaborasi dengan guru bidang studi Bahasa Inggris kelas VIII-F dalam proses belajar mengajar.

\section{Observasi}

Pada siklus 1 merupakan pelaksanaan penerapan strategi pembelajaran tanggapan aktif dengan 2 kali pertemuan. Pada siklus 1 dibantu oleh dua orang observer yaitu Suhairi dan Suhri. Keduanya diberikan tugas masing-masing untuk mengamati aktivitas belajar siswa. Pertemuan 1 mengamati aktivitas siswa pada mendukung tentang Understanding Expression? Jawaban sementara oleh guru karena peneliti ingin menerapkan fungsi sosial, struktur teks, dan unsur kebahasaan teks interaksi interpersonal lisan dan tulis yang melibatkan tindakan meminta perhatian, mengecek pemahaman, menghargai kinerja, meminta dan mengungkapkan pendapat, serta menanggapinya, sesuai dengan konteks penggunaannya. Sedangkan Pertemuan 2 mengamati aktivitas siswa pada menolak. Guru meminta siswa untuk memberikan alasan yang tepat dan mendiskusikan dengan anggota kelompok.

. Pada kegiatan prasiklus nilai klasikal siswa 50\%, hal ini masih dibawah rata-rata nilai dari SMP Negeri 1 Situbondo yaitu 72,79 kemudian KKM yang ditetapkan $85 \%$ maka peneliti mengambil tindakan dengan menerapkan Penerapan strategi pembelajaran tanggapan aktif yang mampu untuk mengatasi kesulitan belajar siswa.

Tabel 4.2 Hasil Belajar siswa Siklus 1

\begin{tabular}{|c|c|c|}
\hline Nilai Siswa & Jumlah siswa & Persentase \\
\hline$\geq 70$ & 32 siswa & $76 \%$ \\
\hline$<70$ & 8 siswa & $24 \%$ \\
\hline
\end{tabular}

Gambar 4.2 Hasil Belajar siswa Siklus 1

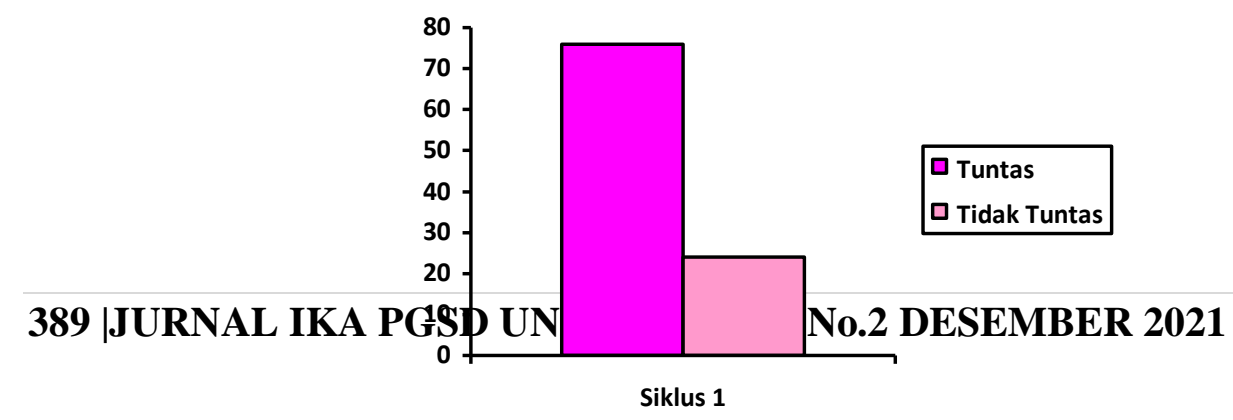


Berdasarkan chart 4.2 menunjukkan bahwa terjadi peningkatan yang pesat pada prosentase hasil observasi tingkah laku siswa dalam keterlibatan siswa dalam belajar mengajar, antara lain meliputi siswa tidak takut atau berani dalam mengemukakan pendapat dalam belajar kelompok pada analisis observasi I di siklus I. sedangkan hasil belajar pada siklus 1 ketuntasan belajar siswa kelas VIIIF yaitu secara klasikal mencapai $76 \%$ atau 32 siswa yang tuntas dan siswa yang belum tuntas 8 siswa atau 24\%. Hasil observasi hasil belajar siswa mencapai ketuntasan $76 \%$ dan perlu diadakan siklus 2 karena masih belum mencapai ketuntasan klasikal sesuai yang ditetapkan oleh sekolah. Dalam penelitian ini tidak hanya siswa yang melakukan kesalahan namun guru perlu di observasi oleh teman sejawat yaitu Pertemuan 2 dan Pertemuan 1 yang kebetulan mengadakan penelitian di kelas VIII-F. Adapun hasil observasi guru dapat dilihat pada tabel 4.3 dan 4.4 sebagai berikut:

Tabel 4.3 Hasil Observasi Aktivitas Guru Siklus 1 Observer Pertemuan 1

\begin{tabular}{|c|c|c|c|c|}
\hline \multirow{2}{*}{ No } & \multirow{2}{*}{ Aspek yang diamati } & \multicolumn{2}{|c|}{ Observer } & \multirow{2}{*}{ Keterangan } \\
\hline & & $\mathrm{Ya}$ & Tidak & \\
\hline 1. & $\begin{array}{l}\text { Guru menyampaikan tujuan } \\
\text { pembelajaran }\end{array}$ & $\sqrt{ }$ & & \\
\hline 2. & $\begin{array}{l}\text { Kemampuan mengorganisir siswa } \\
\text { dalam kelompok belajar (membentuk } \\
\text { kelompok). }\end{array}$ & $\sqrt{ }$ & & \\
\hline 3. & $\begin{array}{l}\text { Guru membimbing siswa dalam siap } \\
\text { kegiatan pembelajaran }\end{array}$ & & $\sqrt{ }$ & \\
\hline 4. & $\begin{array}{l}\text { Guru membimbing siswa untuk } \\
\text { membaca kembali buku pelajaran }\end{array}$ & & $\sqrt{ }$ & \\
\hline 5. & $\begin{array}{l}\text { Guru menunjukkan contoh artikel } \\
\text { yang berhubungan dengan materi }\end{array}$ & & $\sqrt{ }$ & \\
\hline
\end{tabular}

Tabel 4.4 Hasil Observasi Aktivitas Guru Siklus 1 Observer Pertemuan 2

\begin{tabular}{|c|c|c|c|c|}
\hline \multirow{2}{*}{ No } & \multirow{2}{*}{ Aspek yang diamati } & \multicolumn{2}{|c|}{ Observer } & \multirow{2}{*}{ Keterangan } \\
\hline & & $\mathrm{Ya}$ & Tidak & \\
\hline 1. & $\begin{array}{l}\text { Guru menyampaikan tujuan } \\
\text { pembelajaran } \\
\text { Kemampuan mengorganisir siswa } \\
\text { dalam kelompok belajar (membentuk } \\
\text { kelompok). } \\
\text { Guru membimbing siswa dalam siap } \\
\text { kegiatan pembelajaran }\end{array}$ & $\sqrt{ }$ & & \\
\hline
\end{tabular}




\begin{tabular}{|l|l|l|l|l|}
\hline 3. & $\begin{array}{l}\text { Guru membimbing siswa untuk } \\
\text { membaca kembali buku pelajaran } \\
\text { Guru menunjukkan contoh artikel } \\
\text { yang berhubungan dengan materi }\end{array}$ & $\sqrt{ }$ & \\
\hline
\end{tabular}

Hasil observasi guru sudah jelas terlihat bahwa guru kurang mampu untuk memberikan bimbingan kepada tiap-tiap keompok, masih terlihat kaku dalam menerapkan strategi pembelajaran tanggapan aktif. kelompoknya.

\section{Refleksi}

Ketuntasan belajar siswa secara klasikal mencapai $76 \%$ atau 32 siswa yang tuntas, maka perlu adanya perbaikan pada siklus ke II untuk perbaikan pada hasil belajar siswa dengan cara pada siklus I guru yang menentukan anggota dalam kelompok namun pada siklus II, guru memberikan kesempatan kepada siswa untuk memilih dan menentukan anggota kelompok yang dianggap bagi kelompok tersebut mampu untuk membimbing anggotanya. Siswa diberikan kesempatan untuk menjelaskan materi melalui artikel yang diterima dengan terlebih dahulu menjawab pertanyaan dari pertanyaan.

Tabel 4.5 Rekapitulasi Prasiklus dan Siklus I

\begin{tabular}{|l|c|c|c|c|c|}
\hline \multirow{2}{*}{ Nilai } & \multicolumn{3}{|c|}{ Siklus } & \multirow{2}{*}{ Peningkatan } \\
\cline { 2 - 5 } & \multicolumn{2}{|c|}{ Prasiklus } & \multicolumn{2}{c|}{ Siklus I } & \\
\cline { 2 - 4 } & Jumlah/Prosentase & Jumlah/Prosentase & \\
\hline$\geq 70$ & 17 & $50 \%$ & 26 & $76 \%$ & \multirow{2}{*}{$26 \%$} \\
\hline$\leq 70$ & 17 & $50 \%$ & 8 & $24 \%$ & \\
\hline
\end{tabular}

\section{Pelaksanaan Siklus II}

Perencanaan

Siklus 1 terlihat bahwa guru memberikan kesempatan kepada siswa untuk memilih dan menentukan anggota kelompok yang dianggap bagi kelompok tersebut mampu untuk membimbing anggotanya. Siswa diberikan kesempatan untuk menjelaskan materi melalui artikel koran yang diterima dengan terlebih dahulu menjawab pertanyaan dari pertanyaan yang diajukan oleh siswa lain bahkan guru membimbing siswa untuk membaca kembali buku pelajaran. Guru kurang meminta siswa untuk membaca kembali untuk menemukan jawaban atau masalah yang sebenarnya pada suatu Understanding Expression. Pada saat pembelajaran guru menunjukkan contoh kalimat yang menggunakan Understanding Expression. Bahkan guru kurang persiapan sehingga guru kurang menguasai materi dan menguasai kelas yang terkesan ramai. Maka dalam 
kegiatan perencanaan guru lebih memberikan suatu peayanan yang baik kepada siswa agar siswa mampu menjelaskan materi atau jawabannya kepda siswa lain.

Kegiatan yang dilakukan pada tahap perencanaan ini adalah melaksanakan kegiatan sesuai dengan desain yang telah dibuat sebelumnya (seperti yang dijelaskan pada siklus I), pada tahap ini semua persiapan telah dilakukan setelah dilakukan diskusi antara guru, peneliti dan observer, baik yang berkaitan dengan persiapan mengajar (menyusun rencana pembelajaran pada Pokok Bahasan yang akan dibahas, gambar dan perlengkapan dalam Pokok Bahasan yang akan dibahas, soal sebagai bahan diskusi baik diluar kelas maupun di dalam kelas dan kunci jawaban serta mempersiapkan deskriptif tugas tim peneliti.

\section{Pelaksanaan Tindakan}

\section{Pertemuan Ketiga}

Siswa mampu mengembangkan ide-idenya sendiri dan mengungkapkan pendapat tentang hubungan antara pengalaman dengan pengetahuan yang mereka dapat saat itu. Siswa menjawab pertanyaan dengan menunjukkan bukti. Kegiatan penutup dengan guru memberikan tugas pelajaran rumah melalui LKS, pemberian tugas melalui LKS dimaksudkan untuk menyeimbangkan pengetahuan. Siswa yang telah didapat melalui diskusi.

Pertemuan Keempat

Kegiatan pendahuluan selama 10 menit dengan guru memberikan apersepsi kepada siswa sesuai dengan materi yang akan dibahas Kegiatan inti selama 60 menit dengan guru mengembangkan sebuah pernyataan yang kontroversial yang berkaitan dengan materi Understanding Expression. Contohnya tahukah kamu tentang Understanding Expression? Guru membuat dua sampai empat sub kelompok dalam masing-masing kelompok untuk memberikan tanggapan. Guru mempersiapkan dua sampai empat kursi untuk juru bicara pada kelompok. Setelah mendengarkan argument pembuka, hentikan debat dan kembali ke sub kelompok. Setiap sub kelompok memilih juru bicara, usahakan yang baru. Siswa dapat melanjutkan kembali tanggapan Pada saat yang tepat akhiri tanggapan. Kegiatan penutup selama 10 menit dengan guru memberikan tugas pelajaran rumah untuk menyeimbangkan pengetahuan. Siswa yang telah didapat melalui diskusi. 
Kegiatan ketiga dan keempat sama dalam siklus 2 guru lebih membimbing siswa untuk mampu menjelaskan materi kepada siswa lain dengan percaya diri. Maka dalam hal ini peneliti tidak menjelaskan secara detail kembali tentang pertemuan keempat siklus 2 tersebut.

\section{Observasi}

Pada siklus 1 merupakan pelaksanaan penerapan strategi pembelajaran tanggapan aktif dengan 2 kali pertemuan. Pada siklus 2 ada peningkatan hasil belajar siswa dari pada kegiatan prasiklus yaitu dengan wawancara dengan guru mata pelajaran Bahasa Inggris yang menyatakan bahwa siswa kelas VIII-F belum optimal dalam mengatasi kesulitan belajar dan tidak aktif dalam belajar sehingga hanya guru yang aktif dalam pembelajaran ini. Pada kegiatan siklus 2 nilai klasikal siswa 94\%, hal ini masih dibawah rata-rata nilai dari SMP Negeri 1 Situbondo yaitu 81,32 kemudian KKM yang ditetapkan 85\% maka peneliti mengambil tindakan dengan menerapkan strategi pembelajaran tanggapan aktif yang mampu untuk mengatasi kesulitan belajar siswa.

Tabel 4.6 Hasil Observasi Aktivitas Guru Siklus II Pertemuan 3

\begin{tabular}{|c|c|c|c|c|}
\hline \multirow{2}{*}{ No } & \multirow{2}{*}{ Aspek yang diamati } & \multicolumn{2}{|c|}{ Observer } & \multirow{2}{*}{ Keterangan } \\
\hline & & $\mathrm{Ya}$ & Tidak & \\
\hline 1. & $\begin{array}{l}\text { Guru menyampaikan tujuan } \\
\text { pembelajaran }\end{array}$ & $\sqrt{ }$ & & \\
\hline 2. & $\begin{array}{l}\text { Kemampuan mengorganisir siswa } \\
\text { dalam kelompok belajar (membentuk } \\
\text { kelompok). }\end{array}$ & $\sqrt{ }$ & & \\
\hline 3. & $\begin{array}{l}\text { Guru membimbing siswa dalam siap } \\
\text { kegiatan pembelajaran }\end{array}$ & $\sqrt{ }$ & & \\
\hline 4. & $\begin{array}{l}\text { Guru membimbing siswa untuk } \\
\text { membaca kembali buku pelajaran }\end{array}$ & $\sqrt{ }$ & & \\
\hline 5. & $\begin{array}{l}\text { Guru menunjukkan contoh artikel } \\
\text { yang berhubungan dengan materi }\end{array}$ & $\sqrt{ }$ & & \\
\hline
\end{tabular}

Tabel 4.7 Hasil Observasi Aktivitas Guru Siklus II Pertemuan 4

\begin{tabular}{|c|l|c|c|c|}
\hline \multirow{2}{*}{ No } & \multicolumn{1}{|c|}{ Aspek yang diamati } & \multicolumn{2}{|c|}{ Observer } & \multirow{2}{*}{ Keterangan } \\
\cline { 2 - 4 } 1. & $\begin{array}{l}\text { Guru menyampaikan tujuan } \\
\text { pembelajaran }\end{array}$ & $\sqrt{ }$ & & \\
$\begin{array}{l}\text { Kemampuan mengorganisir siswa } \\
\text { dalam kelompok belajar (membentuk } \\
\text { kelompok). }\end{array}$ & $\sqrt{ }$ & & \\
$\begin{array}{l}\text { Guru membimbing siswa dalam siap } \\
\text { kegiatan pembelajaran }\end{array}$ & $\sqrt{ }$ & & \\
\hline
\end{tabular}




\begin{tabular}{|l|l|l|l|l|}
\hline 4. & $\begin{array}{l}\text { Guru membimbing siswa untuk } \\
\text { membaca kembali buku pelajaran }\end{array}$ & $\sqrt{ }$ & \\
5. $\begin{array}{l}\text { Guru menunjukkan contoh artikel } \\
\text { yang berhubungan dengan materi }\end{array}$ & $\sqrt{ }$ & & \\
\hline
\end{tabular}

\section{Refleksi}

Hasilnya semua siswa masuk mengikuti tes, masih ada 2 anak yang bersikap kebingungan meminta bantuan temannya terutama yang duduk di belakang anak ini tergolong nakal sering bolos. Guru dan peneliti sama-sama menggunakan catatan bebas. Setelah melakukan peninjauan pada setiap siswa terlihat mereka mulai memperhatikan kerapian dalam menulis, ada yang mulai berfikir dengan kritis mereka tidak malu lagi ketika dilihat hasil pekerjaannya. Secara garis besar ulangan atau pelaksanaan tes pada siklus I berjalan dengan lancar dan tertib. Hasil belajar pada siklus II mencapai ketuntasan secara klasikal sebesar $94 \%$ atau sebanyak 32 siswa.

Hasil observasi terhadap guru pada siklus II yang dilakukan oleh peneliti dalam pembelajaran menunjukkan, aktivitas guru sebagai fasilitator kekurangan dalam siklus I sudah teratasi berkat kerjasama tim peneliti. Guru dalam melaksanakan penerapan strategi pembelajaran tanggapan aktif sesuai dengan skenario pembelajaran berpedoman pada indikator aktivitas guru mengajar, maka guru dalam menggunakan penerapan strategi pembelajaran tanggapan aktif dapat dikategorikan baik. Antusias dan ketertarikan siswa terlihat dalam hal mengeluarkan pendapat dan bertanya saat guru memberikan presentasi mengenai manfaat mempelajari materi. Siswa mulai menunjukkan peningkatan kemampuan berfikir kreatif dalam mengerjakan soal-soal. Guru memotivasi siswa dengan menginformasikan bahwa nilai yang telah mereka peroleh saat pelaksanaan siklus I yang masih rendah, sehingga memunculkan dorongan kepada mereka untuk berusaha meningkatkan hasil belajar pada siklus II.

Berdasarkan analisis terhadap hasil pekerjaan siswa, dapat Diketahui bahwa sebagian besar siswa sudah dapat mengungkapkan pengertian tentang Understanding Expression. Pelaksanaan tes pada siklus II, hasil yang dicapai dari tes tersebut sudah menunjukkan nilai yang sesuai dengan kriteria ketuntasan baik secara klasikal maupun secara individu. Pada hasil analisis tes pada siklus II, diketahui sudah sebagian besar siswa telah memahami konsep analisis tes pada 
siklus II, diketahui sudah sebagian besar siswa telah memahami konsep dan soalsoal Understanding Expression itu sendiri dengan baik, yang ditunjukkan dengan peningkatan hasil belajar secara klasikal 94\%. Hasil tes pada siklus II menunjukkan ada 2 siswa yang memperoleh nilai $<70$ dan sebanyak 32 siswa atau sebesar 94\% yang memperoleh nilai $\geq 70 \%$.

Tabel 4.8 Rekapitulasi Prasiklus, Siklus I dan Siklus II

\begin{tabular}{|c|c|c|c|c|c|c|c|c|}
\hline \multirow{3}{*}{ Nilai } & \multicolumn{6}{|c|}{ Siklus } & \multirow{3}{*}{\multicolumn{2}{|c|}{ Peningkatan }} \\
\hline & & dus & & & Sikl & & & \\
\hline & \multicolumn{2}{|c|}{ Jumlah/Prosentase } & \multicolumn{2}{|c|}{ Jumlah/Prosentase } & \multicolumn{2}{|c|}{ Jumlah/Prosentase } & & \\
\hline$\geq 70$ & 17 & $50 \%$ & 26 & $76 \%$ & 32 & $94 \%$ & \multirow{2}{*}{$26 \%$} & \multirow{2}{*}{$18 \%$} \\
\hline$<70$ & 17 & $50 \%$ & 8 & $24 \%$ & 2 & $6 \%$ & & \\
\hline
\end{tabular}

Berdasarkan pelaksanaan siklus penelitian yang meliputi dua siklus diperoleh beberapa temuan penelitian.

1) Pada pelaksanaan siklus I diikuti oleh 32 siswa. Tes terakhir menunjukkan ketuntasan klasikal mencapai 76\%. Dari 32 siswa tersebut ada 8 orang yang masih mendapat nilai dibawah 70. dalam pelaksanaan tes ada beberapa siswa yang tidak masuk, hal ini juga mempengaruhi ketuntasan belajar. Kesimpulan yang diperoleh akhirnya pelaksanaan pembelajaran pada siklus 1 belum berhasil maka penelitian dilanjutkan pada siklus II;

2) Pada siklus II, tetap diikuti 34 siswa dan hasil pelaksanaan tes diperoleh ada 2 siswa belum tuntas belajarnya, sedangkan ketuntasan belajar secara klasikal baik yang ditunjukkan semakin antusiasnya penerapan strategi pembelajaran tanggapan aktif .

3) Dari hasil observasi pada jawaban tes dan analisis hasil tes pada siklus I, Diketahui bahwa rata-rata kesalahan yang dilakukan siswa, dikarenakan siswa terburu-buru dalam memahami pertanyaan sehingga siswa Melihat teman yang lain sudah selesai mengerjakan soal maka siswa dalam menjawab pertanyaan tersebut terkesan sembarangan. Dengan begitu siswa yang kurang memahami soal dan mengerti soal serta adanya kecerobohan dari siswa sendiri sehingga pekerjaan siswa kurang sempurna.

4) Dari hasil analisis tes pada siklus I diperoleh klasikal sebesar $76 \%$. Hal ini menunjukkan bahwa penerapan pembelajaran strategi pembelajaran tanggapan aktif pada siklus I belum berhasil. Berangkat ketidakberhasilan pada siklus I maka penelitian melanjutkan tindakan perbaikan dengan melaksanakan siklus 
II. Hasil analisis tes pada siklus II diperoleh ketuntasan klasikal sebesar 94\%. Dengan Keberhasilan siswa pada tes di siklus II, hal ini menunjukkan bahwa pembelajaran dengan pendekatan peer tutorial telah berhasil dan dapat membawa siswa kepada hasil belajar yang semakin meningkat yang ditunjukkan dengan adanya ketuntasan secara individu dengan nilai ketuntasan sebesar $\geq 70 \%$ dan secara klasikal $\geq 94 \%$ ketercapaian.

Berdasarkan temuan penelitian yang diperoleh dalam penelitian tindakan kelas tersebut, maka dapat disimpulkan bahwa sebenarnya siswa memperoleh suasana belajar yang menyenangkan, antusias dalam mengikuti pembelajaran. Siswa saling bekerjasama dalam memecahkan soal-soal yang di anggap sulit dan menambah keakraban antara teman sebangku. Adanya pelaksanaan tes yang terjadwal membuat siswa mempunyai waktu untuk belajar. Pengakuan yang diberikan guru atas usaha siswa dalam mengikuti pembelajaran memberi semangat siswa untuk belajar.

\section{PEMBAHASAN}

Pembelajaran dengan menggunakan penerapan strategi pembelajaran tanggapan aktif adalah pelaksanaan pembelajaran dengan menerapkan empat komponen yang berpengaruh pada pembelajaran di kelas yakni keterampilan bertanya, menjawab pertanyaan, keterampilan menggarisbawahi dan keterampilan merangkum. Pembelajaran ini mampu meningkatkan kemampuan psikomotorik siswa, mengoptimalkan penggunaan pemahaman siswa pada konsep materi siswa yang dapat berpengaruh besar pada pembelajaran tugas, merumuskan masalah, mengemukakan pendapat dan menjawab pertanyaan baik dari guru maupun dari siswa.

Penerapan strategi pembelajaran tanggapan aktif dapat mengaktifkan siswa aktif dalam kegiatan belajar mengajar, karena mereka dibimbing untuk mendapatkan pengetahuannya sendiri dengan memperhatikan penampilan materi Understanding Expression melalui media pembelajaran, sehingga siswa benarbenar memiliki gambaran pengetahuan mengenai materi. Siswa juga dapat memiliki pengetahuan melalui pengalaman belajarnya dengan cara menyelesaikan tugas sehingga dapat saling bertukar pikiran dengan siswa lain, lebih leluasa mengeluarkan pendapat berkaitan dengan materi yang dikuasai, serta lebih berani 
bertanya dan menjawab berkaitan dengan materi yang dikuasai, serta lebih berani bertanya dan menjawab hal-hal yang berkenan dengan materi, dengan demikian siswa dapat lebih mudah dalam memahami materi.

Selama pelaksanaan penerapan strategi pembelajaran tanggapan aktif , siswa tampak aktif dan antusias dalam mengikuti kegiatan belajar mengajar. Pada pelaksanaan siklus I diikuti oleh 34 siswa. Tes terakhir menunjukkan ketuntasan klasikal mencapai $76 \%$. Dari 34 siswa tersebut ada 8 orang yang masih mendapat nilai dibawah 70. dalam pelaksanaan tes ada beberapa siswa yang tidak masuk, hal ini juga mempengaruhi ketuntasan belajar. Kesimpulan yang diperoleh akhirnya pelaksanaan pembelajaran pada siklus 1 belum berhasil maka penelitian dilanjutkan pada siklus II hal ini disebabkan oleh siswa masih bingung dengan model pembelajaran yang guru terapkan padahal masing-masing siswa diberikan kartu indek yang berisi materi pelajaran. Pada siklus II, tetap diikuti oleh 34 siswa dan hasil pelaksanaan tes diperoleh ada 2 siswa yang belum tuntas belajarnya, sedangkan ketuntasan belajar secara klasikal baik yang ditunjukkan semakin antusiasnya siswa dengan penerapan strategi pembelajaran tanggapan aktif .

Analisis ulangan harian pada siklus II dapat dilihat pada lampiran. Berdasarkan hasil tersebut diperoleh data dari 34 siswa yang mengikuti ulangan harian 2 siswa yang tidak tuntas belajar, karena siswa tersebut memperoleh nilai kurang dari 70 dari skor maksimal 100 dan 32 siswa tuntas secara perorangan. Hasil tersebut mengalami peningkatan dari siklus I ini dapat terlihat dari ketuntasan belajar. Ketuntasan belajar prasiklus sebesar 50\% dan siklus II sebesar 94\%. Sedangkan ketuntasan belajar secara klasikal pada siklus I hanya mencapai $76 \%$, pada siklus II ini sudah mencapai standar ketuntasan klasikal yang diterapkan pihak sekolah yakni mencapai $85 \%$. Pada hasil belajar siswa pada siklus II sudah mengalami peningkatan dari siklus sebelumnya, meskipun peningkatannya tidak terlalu tinggi dikarenakan dalam mengerjakan tugas kurang teliti.

Peningkatan hasil belajar siswa menunjukkan bahwa penerapan strategi pembelajaran tanggapan aktif dapat dipertimbangkan sebagai pendekatan pembelajaran yang baik diterapkan pada mata pelajaran Bahasa Inggris yang sangat berkaitan dengan kehidupan sehari-hari. Tanggapan guru mengenai penerapan strategi pembelajaran tanggapan aktif sangat mendukung pembelajaran 
ini, karena guru dapat memperbaiki proses pembelajaran yang telah dilaksanakan dengan lebih efektif dan efisien.

\section{DAFTAR PUSTAKA}

Arikunto, 2006. Prosedur Penelitian Suatu Pendektan Praktik. Jakarta: Rineka Cipta

Daryanto, 2009. Psikologi Pendidikan, Rineka Cipta, Jakarta: Rineka Cipta

Djamarah, 2004. Guru dan Anak Didik Dalam Interaksi Edukatif. Jakarta: Rineka Cipta

Hisyam Zaini, 2009. Peningkatan kemampuan berpikir dengan Teknik Modeling pada Siswa Kelas II D SLTP 1 Sukorejo Kendal. Skripsi. 2004

L. Dee Fink, 2001. The Role of Cooperative Learning in Increasing Problem Solving Ability in a College Remedial Course. Journal for Research in Education.

Maleong, 2002. Metodologi Penelitian Kualitatif. Bandung: PT. Remaja Rosdakarya

Mel Silberman, 2009. Pembelajaran Aktif 101 Strategi untuk Mengajar Secara Aktif. Jakarta: Indeks

Mulyasa, 2004. Kurikulum Berbasis Kompetensi. Bandung PT. Remaja Rosdakarya

Nasution, 2007. Metode Penelitian Tindakan. Surabaya: SIC Surabaya

Ningtiash, 2007. Dasar-Dasar Kependidikan. Jakarta: Ditjen Kependidikan

Purwanti (2006. Dasar-dasar Proses Belajar Mengajar. Bandung: PT. Remaja Rosdakarya

Sriyono, 2006. Strategi Pembelajaran Yang Efektif Dan Efisien. Jakarta: Grasindo Sudjana, 2006. Penilaian Hasil Belajar Mengajar. Bandung : Remaja Rosdakarya Trinandita, 2004. Psikologi Pendidikan. Jakata: PT Raja Grafindo Persada Zuriah, 2003. Dasar-dasar Proses Belajar Mengajar. Bandung : PT. Remaja Rosdakarya 